\title{
ANALISIS PENERAPAN SISTEM INFORMASI MANAJEMEN DAN KOMPETENSI PEGAWAI SERTA PENGARUHNYA TERHADAP KINERJA PEGAWAI
}

\author{
Suyitno \\ Sekolah Tinggi Ilmu Ekonomi (STIE) Indonesia Malang, email: drsuyitno@yahoo.co.id
}

\begin{abstract}
The study titled "The study of the influence of the use of information systems and employee competence on the performance of employees in the Board of Industry and Trade Fakfak Regency ", was conducted with the aim to know how the influence of the application of management information systems to employee performance in the Department of Industry and Trade in Fakfak Regency.The research was conducted by survey the use of management information system, the application of competence and its effect on employee performance. Survey is done by observation method and comprehensive interview to respondent. The number of respondents is 40 people who are also employees in Department of Industry and Trade in Fakfak Regency, the data obtained through the questionnaire is then analyzed with the help of SPSS vers 11.5 program. Based on the result of the research, it can be seen that the application of management information system significantly influence the performance of employees at Department of Industry and Trade in Fakfak Regency, with regression coefficient 0,650 (p-value $=0.000)$. Employee competence significantly affects the performance of employees at Department of Industry and Trade in Fakfak Regency, with a regression coefficient of 0.679 ( $p$ value $=0.000)$. This shows that the competence of employees, will drive the performance of government agencies directly by 67.9\%. Implementation of management information system and employee competence together significantly affect the performance of employees at Department of Industry and Trade in Fakfak Regency of $68.1 \%$.
\end{abstract}

Keywords: Management Information System, Competance Employee, Employee Performance

\begin{abstract}
Abstrak
Penelitian dengan judul "Studi pengaruh penggunaan sistem informasi dan kompetensi karyawan terhadap kinerja pegawai di Dewan Perindustrian dan Perdagangan Kabupaten Fakfak", dilakukan dengan tujuan untuk mengetahui bagaimana pengaruh penerapan sistem informasi manajemen terhadap kinerja pegawai di Dinas Perindustrian dan Perdagangan Kabupaten Fakfak. Penelitian dilakukan dengan survei penggunaan sistem informasi manajemen, penerapan kompetensi dan pengaruhnya terhadap kinerja karyawan. Survei dilakukan dengan metode observasi serta wawancara komprehensif kepada responden. Jumlah responden adalah 40 orang yang juga sebagai pegawai di Dinas Perindustrian dan Perdagangan Kabupaten Fakfak , data yang diperoleh melalui kuesioner kemudian dianalisis dengan bantuan program SPSS vers 11,5. Berdasarkan hasil penelitian, terlihat bahwa Penerapan sistem informasi manajemen signifikan mempengaruhi kinerja pegawai di Dinas Perindustrian dan Perdagangan Kabupaten Fakfak, dengan koefisien regresi sebesar 0,650 $(p$-value $=0.000)$. Kompetensi pegawai signifikan mempengaruhi kinerja pegawai di Dinas Perindustrian dan Perdagangan Kabupaten Fakfak, dengan koefisien regresi sebesar 0,679 ( $p$-value $=0.000$ ). Hal ini menunjukkan bahwa kompetensi pegawai, akan mendorong naiknya kinerja instansi pemerintah secara langsung sebesar $67,9 \%$. Penerapan sistem informasi manajemen dan kompetensi pegawai secara bersama signifikan mempengaruhi kinerja pegawai di Dinas Perindustrian dan Perdagangan Kabupaten Fakfak sebesar $68,1 \%$.
\end{abstract}

Kata Kunci: Sistem Informasi Manajemen, Kompetensi Karyawan, Kinerja Karyawan 


\section{PENDAHULUAN}

Pelimpahan wewenang dari pemerintah pusat kepada pemerintah daerah memungkinkan terjadinya penyelenggaraan pelayanan dengan jalur birokrasi yang lebih ringkas dan memberikan peluang bagi pemerintah daerah dalam pemberian dan peningkatan kualitas layanan. Pelaku pelayanan umum di Indonesia adalah aparatur negara sebagai abdi negara dan abdi masyarakat yang didalamnya terdapat kelompok yang dominan baik dalam hal peran layanannya maupun dalam hal jumlah layanan yang diberikan oleh pemerintah untuk memenuhi kepentingan umum (Mustafa, Santiadji. 2011). Masyarakat tidak hanya menuntut pelayanan publik yang lebih efisien, dan memuaskan, tetapi juga menginginkan perilaku administrasi publik yang lebih responsive dan mencerminkan kepatutan (fairness), keseimbangan etika dan kearifan / good judgment (Kasim, 1984). Tuntutan yang gencar dilakukan oleh masyarakat kepada pemerintah merupakan tuntutan yang wajar yang sudah seharusnya direspon oleh pemerintah dengan melakukan perubahan-perubahan yang terarah dengan semakin terwujudnya penyelenggaraan pemerintah yang baik (Hughes Owen dalam Warella, 2004).

Kemajuan teknologi yang sangat cepat mengharuskan instansi mengikuti perkembangan teknologi, untuk itu suatu instansi membutuhkan suatu sistem informasi yang mendukung kebutuhan instansi pemerintah dalam menciptakan efisiensi dan efektifitas kerja maupun dalam meningkatkan pelayanan kepada masyarakat. Disamping itu kemajuan teknologi informasi juga merupakan solusi dalam memenuhi aspek transparansi, akuntabilitas dalam partisipasi masyarakat. Keterpaduan sistem penyelenggaraan pemerintah melalui jaringan informasi perlu terus dikembangkan terutama dalam penyelenggaraan pelayanan sehingga memungkinkan tersedianya data dan informasi pada instansi pemerintah yang dianalisis dan dimamfaatkan secara cepat akurat dan aman. informasi dianggap sebagai salah satu faktor produksi dalam lembaga/instansi, karena merupakan piranti penting yang dapat memecahkan berbagai bentuk ketidaktahuan dan ketidakpastian yang sering kali menjadi kendala dalam proses pengambilan keputusan. Oleh sebab itu, dibutuhkan suatu sistem informasi yang selain dapat melakukan semua pengolahan data untuk fungsi manajemen dalam pengambilan keputusan

Penerapan Sistem Informasi Manajemen (SIM) sangat penting bagi Dinas Perindustrian dan Perdagangan Kabupaten Fakfak karena sebelumnya dalam kesehariannya menggunakan pemrosesan data secara manual sehingga begitu banyak data yang hilang serta pemrosesannya begitu memakan banyak waktu serta birokrasi dan prosedur yang berbelit-belit. Namun sekarang dengan adanya penggunaan penerapan SIM untuk menilai kualitas SIM yang sedang di rencanakan, di buat dan yang sedang di gunakan. Pengukuran efektivitas SIM ini merupakan tugas yang kompleks karena adanya kesulitan dalam menelusuri dan mengukur pengaruh SIM melalui faktor yang saling berhubungan. Oleh karena itu para peneliti di bidang SIM membuat ukuran yang mewakili bagi penerapan SIM, misalnya: kepuasan pengguna informasi (user information satisfaction), penggunaan sistem (system usage) dan nilai informasi (information value). Faktor penerapan SIM berhubungan erat dengan pendekatan kepuasan pemakai.

Penerapan SIM merupakan kondisi yang di perlukan bagi kontribusi SIM terhadap kinerja pemakai dan kinerja pegawai. Suatu pengambilan keputusan merupakan peranan pimpinan yang paling penting, dan tersedianya sumber informasi yang reliabel merupakan komponen kunci bagi pembuatan keputusan manajemen. Sumber informasi dapat berbentuk oral, tertulis atau computer-based (sumber informasi yang berbasis komputer). Secara umum sistem informasi dapat mendukung fungsi-fungsi manajemen, mulai dari perumusan tujuan 
dan sasaran sampai evaluasi yang diselenggarakan Dinas Perindustrian dan Perdagangan Kabupaten Fakfak bagi evaluasi program-program peningkatan kinerja pegawai. Dalam usaha peningkatan kinerja pegawai, diperlukan pengadaan system informasi yang akan dianalisis pengaruhnya bagi semua kegiatan yang dilaksanakan. Penelitian mengenai implementasi sistem informasi manajemen di birokrasi pemerintahan ini memiliki rumusan masalah sebagai berikut: Apakah penerapan sistem informasi manajemen dan kompetensi pegawai baik secara parsial maupun simultan berpengaruh signifikan terhadap kinerja pegawai Dinas Perindustrian dan Perdagangan Kabupaten Fakfak? Dan manakah diantara penerapan sistem informasi manajemen dan kompetensi

\section{Tinjauan Teoritis}

\section{- Penerapan Sistem Informasi Manajemen}

Sistem merupakan kegiatan yang saling berhubungan satu sama lain dan saling keterkaitan tersusun secara sistematis. Sistem menurut Jogiyanto adalah Sistem adalah kumpulan dari elemen-elemen yang berinteraksi untuk mencapai suatu tujuan. (Jogiyanto, 1999:4). Maksud dari kutipan tersebut bahwa sistem merupakan kumpulan dari bagian-bagian atau komponen-komponen subsistem atau bagian dari sistem yang saling berinteraksi dan bekerja sama untuk membentuk satu kesatuan dalam menjalankan fungsi tertentu yang mempengaruhi proses dari setiap subsistem atau bagian sistem secara keseluruhan untuk mencapai satu tujuan tertentu.

Menurut Jogiyanto sebuah system memiliki karakteristik tertentu diantaranya adalah sebagai berikut :

1. komponen-komponen (component), komponen-komponen atau elemen-elemen sistem dapat berupa suatu subsistem atau bagian-bagian dari sistem.

2. batas sistem (boundary), batasan sistem merupakan daerah yang membatasi antara suatu sistem pegawai yang dominan mempengaruhi kinerja pegawai Dinas Perindustrian dan Perdagangan Kabupaten Fakfak?

Mengacu pada perumusan masalah tersebut di atas, maka tujuan dari penelitian ini adalah untuk mengetahui dan menganalisi pengaruh penerapan sistem informasi manajemen dan kompetensi pegawai baik ditihat secara parsial maupun secara simultan terhadap kinerja pegawai pada Dinas Perindustrian dan Perdagangan Kabupaten Fakfak. Selain itu juga untuk mengetahui dan menganalisi faktor yang dominan mempengaruhi diantara penerapan sistem informasi manajemen dan kompetensi pegawai terhadap kinerja pegawai pada Dinas Perindustrian dan Perdagangan Kabupaten Fakfak.

dengan sistem yang lainnya atau dengan lingkungan luarnya.

3. lingkungan luar (environment), lingkungan luar dari suatu sistem atau apapun diluar batas dari sistem yang mempengaruhi operasi sistem.

4. penghubung sistem (system interface), penghubung sistem mempunyai media penghubung antara suatu subsistem dengan subsistem yang lainnya.

5. masukan sistem (system input), masukan (input) istem adalah energi yang dimasukan kedalam sistem

6. keluaran sistem (system output) keluaran sistem adalah hasil dari energi yang diolah dan diklasifikasikan menjadi keluaran yang berguna.

7. pengolahan sistem(system processing), suatu sistem dapat mempunyai suatu bagian pengolah yang akan mengubah masukan menjadi keluaran.

8. sasaran sistem, suatu sistem mempunyai tujuan (goal) atau sasaran (objektive) lingkungan luar. (Jogiyanto, 1999:13).

Berdasarkan penjelasan di atas, maka antara sistem, data dan informasi 
Suyitno, Analisis Penerapan Sistem Informasi Manajemen dan Kompetensi Pegawai...

memiliki kesinambungan yang saling melengkapi. Data merupakan bahan baku atau bahan awal bagi suatu informasi dari data-data yang masih bersifat acak

\section{- Sistem Informasi Manajemen}

Menurut A. Anwar (2000) sistem informasi adalah kombinasi antara prosedur kerja, informasi, orang, dan teknologi informasi yang diorganisasikan untuk mencapai tujuan dalam sebuah organisasi . Pendapat tersebut mengemukakan, bahwa sistem informasi merupakan kumpulan kegiatan yang diintegrasikan antara program kerja, informasi ke dalam suatu server database sehingga keinginan suatu organiasi dalam mencapai tujuan bisa terwujudkan.

Manajemen sebagai penggerak dan pengendali suatu organisasi sangat tergantung kepada informasi yang diterimanya. Keputusan yang harus diambil saat melaksanakan fungsinya akan sulit dilakukan seandainya manajemen tersebut tidak mendapatkan informasi yang mencerminkan keadaan sebenarnya. Azhar Susanto berpendapat bahwa Sistem Informasi Manajemen adalah:"Merupakan kumpulan dari subsub sistem yang saling berhubungan satu sama lain dan bekerja sama secara harmonis untuk mencapai satu tujuan yaitu mengolah data menjadi informasi yang diperlukan oleh manajemen dalam proses pengambilan keputusan saat melaksanakan fungsinya". (Azhar Susanto, 2004:68).

Jadi sistem informasi manajemen memiliki fungsi untuk merencanakan, menyusun (mengorganisir), menempatkan, mengarahkan dan mengendalikan apakah rencana yang dibuat telah terealisasi dengan baik yang bertujuan untuk pengambilan keputusan.

\section{- Kompetensi Pegawai}

Kualitas sumber daya manusia adalah kemampuan sumber daya manusia untuk melaksanakan tugas dan tanggung jawab yang diberikan kepadanya dengan bekal pendidikan, pelatihan, dan pengalaman yang cukup memadai. (Chung, Kae $\mathrm{H}$ and Leon C Megginsons, kenudian data tersebut disaring untuk mendapatkan informasi yang akurat, jelas dan dapat dipertanggungjawabkan.

(1981). Lucas, H.C, Jr, (1974) mendefinisikan bahwa "Sumber daya manusia merupakan pilar penyangga utama sekaligus penggerak roda organisasi dalam usaha mewujudkan visi dan misi serta tujuan dari organisasi tersebut". Sumber daya manusia merupakan salah satu elemen organisasi yang sangat penting, oleh karena itu harus dipastikan bahwa pengelolaan sumber daya manusia dilakukan sebaik mungkin agar mampu memberikan kontribusi secara optimal dalam upaya pencapaian tujuan organisasi.

Dukungan SDM aparatur dalam melaksanakan tugas pokok dan fungsi serta kewajibannya mempunyai kemampuan atau kompetensi yang baik, pelayanan diberikan secara transparan, fair, tidak membeda-bedakan dan dilaksanakan secara akuntabel serta penuh keikhlasan dan ketulusan. Kompetensi jabatan SDM aparatur (PNS), secara umum berarti kemampuan dan karakteristik yang dimiliki seorang PNS berupa pengetahuan, keterampilan, sikap, dan perilaku, yang diperlukan dalam pelaksanaan tugas jabatannya (Suyitno, 2017). Disinilah kompetensi menjadi satu karakteristik yang mendasari individu atau seseorang mencapai kinerja tinggi dalam pekerjaannya. Karakteristik itu muncul dalam bentuk pengetahuan (knowledge), keterampilan (skill), dan perilaku (attitude) untuk menciptakan aparatur yang memiliki semangat pengabdian yang tinggi dalam melayani masyarakat yang selalu bertindak hemat, efisien, rasional, transparan, dan akuntabel (Laksamana, 2002).

\section{- Kinerja Pegawai}

Flipo (1984:14) menyatakan bahwa "seseorang agar mencapai kinerja yang tinggi tergantung pada kerjasama, kepribadian, kepandaian yang beraneka ragam, kepemimpinan, keselamatan, pengetahuan pekerjaan, kehaditan 
kesetiaan, ketangguhan dan inisiatif". Kerjasama antar pegawai yang ada di organisasi tersebut dalam rangka melaksanakan tugas dan pekerjaannya, baik kerjasama antara atasan dan bawahan maupun kerjasama antar bawahan. Kepribadian para pegawai menentukan baik buruknya hasil kerja.. Kinerja pegawai dipengaruhi oleh kerjasama, kepribadian yang beraneka ragam, kepemimpinan, keselamatan, pengetahuan pekerjaan, kehadiran, kesetiaan, ketangguhan dan inisiatif produktifitas sangat perlu mendapatkan perhatian dari pihak manajemen organisasi.

Kinerja diukur dengan instrumen yang dikembangkan dalam studi yang tergantung dengan ukuran kinerja secara umum, kemudian diterjemahkan ke dalam penilaian perilaku secara mendasar yang dapat meliputi berbagai hal: kuantitas pekerjaan, kualitas pekerjaan, pendapat atau pernyataan yang disampaikan, keputusan yang diambil dalam melakukan pekerjaan dan deskripsi pekerjaan. Adapun beberapa faktor penentu kinerja menurut Nazier, Daeng M.(2009) yang menjadi indikator dalam penelitian ini, yaitu:

1. Pengetahuan (knowledge), konsep pengetahuan individu berorientasi pada intelenjensi, daya pikir dan penguasaan ilmu yang memberikan kontribusi pada seseorang di dalam memecahkan masalah, daya cipta atau menyelesaikan pekerjaan.

2. Ketrampilan (skill), yaitu kemampuan dan penguasaan teknis operasional mengenai bidang tertentu, yang bersifat kekaryaan.

\section{Kerangka Konseptual Penelitian}

Berdasarkan uraian teori di atas, maka kerangka konseptual penelitian dituangkan dalam bagan sebagai berikut:

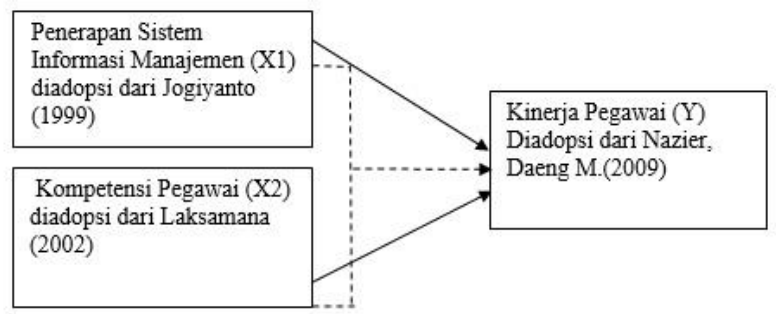

3. Kemampuan (abilities), faktor ini terbentuk dari sejumlah kompetensi yang dimiliki oleh seorang karyawan yang meliputi kemampuan dan ketrampilan.

4. Kebiasaan (attitude) dan perilaku (behaviour), apabila kebiasaan kebiasaan karyawan adalah baik, maka hal tersebut dapat menjamin perilaku kerja yang baik atau efektif.

Kinerja adalah sebuah aksi, bukan kejadian. Aksi kinerja itu sendiri terdiri dari banyak komponen dan bukan merupakan hasil yang dapat dilihat pada saat itu juga. Pada dasarnya kinerja merupakan sesuatu hal yang bersifat individual, karena setiap karyawan memiliki tingkat kemampuan yang berbeda dalam mengerjakan tugasnya. Kinerja tergantung pada kombinasi antara kemampuan, usaha, dan kesempatan yang diperoleh. Hal ini berarti bahwa kinerja merupakan hasil kerja karyawan dalam bekerja untuk periode waktu tertentu dan penekanannya pada hasil kerja yang diselesaikan karyawan dalam periode waktu tertentu. (Timpe, 1993, p. 3). Selain itu Williams mengatakan: "Performance is defined as the record of outcomes produced on a specified job function or activity during a specified time period. Performance on the job as a whole would be equal to the sum (or average) of performace on the critical or essential job functions. The functions have to do with the work which is performed and not with the characteristic of the person performing (Suyitno, 2017).

Gambar 2

Kerangka Konseptul Penelitian 
Suyitno, Analisis Penerapan Sistem Informasi Manajemen dan Kompetensi Pegawai...

\section{Hipotesis Penelitian}

Berdasarkan landasan teori dan kerangka konseptual serta rumusan masalah penelitian yang diajukan, maka hipotesis dalam penelitian ini adalah:

a. Penerapan sistem infromasi manajemen berpengaruh signifikan terhadap kinerja pegawai pada Dinas Perindustrian dan Perdagangan Kabupaten Fakfak.

b. Kompetensi pegawai berpengaruh signifikan terhadap kinerja pegawai pada Dinas Perindustrian dan Perdagangan Kabupaten Fakfak.

c. Penerapan sistem infromasi manajemen dan kompetensi pegawai secara simultan berpengaruh signifikan terhadap kinerja pegawai pada Dinas Perindustrian dan Perdagangan Kabupaten Fakfak.

d. Kompetensi pegawai berpengaruh dominan terhadap kinerja pegawai pada Dinas Perindustrian dan Perdagangan Kabupaten Fakfak.

\section{Metode Penelitian}

\section{- Rancangan Penelitian}

Rancangan penelitian ini merupakan tipe penelitian penjelasan (explanatif research) dengan melakukan pengamatan /non-eksperimen karena menjelaskan hubungan kausal antara variabel-variabel melalui pengujian hipotesis tanpa memberikan perlakuan. Sampel dalam penelitian ini adalah seluruh pegawai di lingkungan Dinas Perindustrian dan Perdagangan Kabupaten Fakfak yang berjumlah 40 orang.

Pengumpulan data primer dalam penelitian ini didukung dengan observasi, wawancara, dan kuesioner dengan responden, di mana pada kuesioner, responden diberikan suatu daftar pertanyaan untuk dijawab, baik secara langsung untuk memperoleh jawaban mereka maupun dengan panduan peneliti jika diperlukan.

\section{- Teknik Analisis Data}

Teknik analisis data yang digunakan pada penelitian ini adalah regresi linier berganda dengan menggunakan alat bantu statistik SPSS. Sesuai dengan kerangka konseptual dan hipotesis yang ada, maka dilakukan pengujian data hasil penelitian, dalam penelitian ini selanjutnya menggunakan analisis regresi linier berganda. Analisis ini merupakan analisis yang bersifat kuantitatif, digunakan untuk membuktikan sebagian hipotesis penelitian seperti telah disebutkan di atas. Alasan pemilihan model analisis regresi linier berganda adalah untuk mengetahui hubungan kausal antara variabel-variabel dalam penelitian.

Formulasi model dari analisis regresi linier berganda dalam penelitian ini adalah sebagai berikut :

$$
\begin{aligned}
& \mathrm{Y}=\mathrm{a}+\mathrm{b}_{1} \mathrm{X}_{1}+\mathrm{b}_{2} \mathrm{X}_{2}+\mathrm{e} \\
& \text { Dimana : } \\
& \mathrm{Y}=\text { Variabel } \\
& \text { terikat } \\
& \text { (depend } \\
& \text { ent) } \\
& \text { pada } \\
& \text { kinerja } \\
& \text { pegawai } \\
& \mathrm{X}_{1} \quad=\text { Variabel } \\
& \text { bebas } \\
& \text { (indepe } \\
& \text { ndent) } \\
& \text { pada } \\
& \text { penerap } \\
& \text { an SIM } \\
& \text { X2 = Variabel } \\
& \text { bebas } \\
& \text { (indepe } \\
& \text { ndent) } \\
& \text { pada } \\
& \text { kompet } \\
& \text { ensi } \\
& \text { a }= \\
& \text { pegawai } \\
& \text { Konstan } \\
& \text { ta } \\
& \mathrm{b}_{1}, \mathrm{~b}_{2}=\text { Koefisien } \\
& \text { regresi } \\
& \text { e }=\text { standar }
\end{aligned}
$$


Kriteria yang digunakan dalam analisa regresi linier berganda ini adalah:

$$
\begin{aligned}
& \text { Ho : } b_{1}-b_{8}=0 \text { : Tidak adanya } \\
& \text { pengaruh yang berarti }
\end{aligned}
$$

Hi $: b_{1}-b_{8} \neq 0$ : Ada pengaruh yang berarti antara variabel bebas terhadap variabel terikat.

\section{Hasil Analisis Data Penelitian}

\section{-Hasil Uji Regresi}

Setelah semua data dari responden dan model diuji validitasnya, maka langkah selanjutnya dilakukan analisis menggunakan regresi linier berganda. Langkah pertama, semua data dari questioner disusun rapi dalam tabel dientry menggunakan software MS exel. Adapun data lengkap yang sudah disusun rapi tersebut akan tampak pada tabel di lampiran. Selanjutnya dilakukan pengolahan data dengan regresi linier berganda software SPSS versi 11,5 sehingga didapat hasil perhitungan dan

\begin{tabular}{|c|c|}
\hline Variabel & Koef. Regre \\
\hline Penerapan SIM & 0,650 \\
\hline Kompetensi pegawai & 0,679 \\
\hline Konstanta & 0.2391 \\
\hline \multicolumn{2}{|l|}{ Dependent Variabel: Y } \\
\hline Multiple R & 0,72456 \\
\hline R square & 0,653143 \\
\hline Adjusted R. Square & 0,52722 \\
\hline Standart Error & 34,54121 \\
\hline F. Ratio & 23.11242 \\
\hline Durbin Watson Test & 2.424576 \\
\hline Sig F & .000 \\
\hline
\end{tabular}
gambar seperti tabel di bawah ini :

\section{Tabel 1}

Ringkasan Hasil Regresi Linier Berganda

Sumber : print out hasil perhitungan statistik
Dari tabel 1 di atas dapat dibuat persamaan regresi linier berganda sebagai berikut :

$$
\mathrm{Y}=0.2391+0,650 \mathrm{X} 1+0,679 \mathrm{X} 2+5,24
$$

Nilai koefisien regresi penerapan sistem informasi manajemen sebesar 0,650 berarti bahwa dengan asumsi variabel lain konstan, meningkatnya penerapan sistem informasi manajemen sebesar 1 point akan mengakibatkan meningkatnya kinerja pegawai sebesar 65\%. Nilai koefisien regresi penerapan sistem informasi manajemen sebesar 0,679 menunjukkan bahwa dengan asumsi variabel lain konstan, meningkatnya penerapan sistem informasi manajemen sebesar 1 point akan menyebabkan meningkatnya kinerja pegawai sebesar $67,9 \%$.

Tabel 1 juga menunjukkan nilai koefisien determinasi $\left(\mathrm{R}^{2}\right)$ sebesar 0,681, hal ini berarti bahwa variabilitas penerapan SIM dan kompetensi pegawai menjelaskan variabilitas kinerja pegawai daearah sebesar $68,1 \%$ sedangkan sisanya sebesar $31,9 \%$ disebabkan oleh variabel lain yang tidak masuk dalam model.

\section{Pengujian Hipotesis}

\section{- Hasil pengujian Hipotesis 1}

$\begin{array}{ll}\text { manajemen } & \text { berpengaruh signifikan } \\ \text { terhadap kinerja pegawai Dinas }\end{array}$
Perindustrian dan Perdagangan Kabupaten

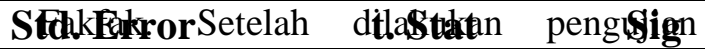

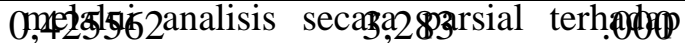
kedua variabel yaitu penerapan sistem

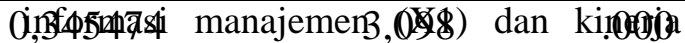
pegawai (y), ternyata variabel penerapan

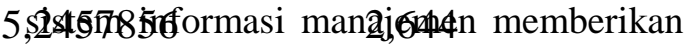
pengaruh yang signifikan terhadap variabel kinerja pegawai dimana signifikansi $\mathrm{t}$ mempunyai nilai 0,000 , dengan nilai regresi $(\beta)$, sebesar 0,650 . Sedangkan koefisien determinansi $\left(\mathrm{r}^{2}\right)$ sebesar 0,356 atau kontribusi yang diberikan variabel penerapan sistem informasi manajemen (X1) terhadap variabel kinerja pegawai (y) adalah sebesar 35,6\%, sehingga masih ada kontribusi dari variabel lain yaitu sebesar $64,4 \%$. 
Suyitno, Analisis Penerapan Sistem Informasi Manajemen dan Kompetensi Pegawai...

\section{- Hasil Pengujian Hipotesis 2}

Kompetensi pegawai berpengaruh signifikan terhadap kinerja pegawai pada Dinas Perindustrian dan Perdagangan Kabupaten FakFak. Setelah dilakukan pengujian melalui analisis regresi sederhana (uji t) terhadap kedua variabel yaitu kompetensi pegawai (X2) dan kinerja pegawai (Y), ternyata variabel kompetensi pegawai memberikan pengaruh yang signifikan terhadap variabel kinerja pegawai dimana signifikansi $\mathrm{t}$ mempunyai nilai 0,000 , dengan nilai regresi $(\beta)$, sebesar 0,679 . Sedangkan koefisien determinansi $\left(\mathrm{r}^{2}\right)$ sebesar 0,610 atau kontribusi yang diberikan variabel kompetensi pegawai (x2) terhadap variabel kinerja instansi pemerintah (y) adalah sebesar 61,0 \%, sehingga masih ada kontribusi dari variabel lain yaitu sebesar 39,0\% .

\section{- Hasil Pengujian Hipotesis 3}

\begin{abstract}
Penerapan sistem informasi manajemen dan kompetensi pegawai secara bersama-sama berpengaruh signifikan terhadap kinerja pegawai pada Dinas Perindustrian dan Perdagangan Kabupaten FakFak. Setelah dilakukan pengujian melalui analisis regresi berganda (uji F) terhadap ketiga variabel yaitu penerapan sistem informasi manajemen (X1), kompetensi pegawai (X2) dan kinerja pegawai (Y), ternyata kedua variabel penerapan sistem informasi manajemen, dan kompetensi pegawai ini memberikan pengaruh yang signifikan terhadap variabel kinerja pegawai dimana signifikansi F mempunyai nilai 0,000. Sedangkan koefisien determinansi (R2) sebesar 0,681 atau kontribusi yang diberikan variabel $\mathrm{x} 1$, dan $\mathrm{x} 2$, secara bersama-sama terhadap variabel kinerja pegawai (y) adalah sebesar 68,1 \%, sehingga masih ada kontribusi dari variabel lain yaitu sebesar 31,9\%.
\end{abstract}

Kompetensi sumber daya manusia mencakup kapasitasnya, yaitu kemampuan seseorang atau individu, suatu organisasi (kelembagaan), atau suatu sistem untuk melaksanakan fungsi-fungsi atau kewenangannya untuk mencapai tujuannya secara efektif dan efisien. Kapasitas harus dilihat sebagai kemampuan untuk mencapai kinerja, untuk menghasilkan keluaran-keluaran (outputs) dan hasil-hasil (outcomes). Untuk menilai kapasitas dan kompetensi sumber daya manusia dalam melaksanakan suatu fungsi, termasuk akuntansi, dapat dilihat dari level of responsibility dan kompetensi sumber daya manusia tersebut. Tanggungjawab dapat dilihat dalam deskripsi jabatan, deskripsi jabatan merupakan dasar untuk melaksanakan tugas dengan baik. Tanpa adanya deskripsi jabatan yang jelas, sumber daya tersebut tidak dapat melaksanakan tugasnya dengan baik (Suyitno, 2017).

Perkembangan teknologi informasi tidak hanya dimanfaatkan pada organisasi bisnis tetapi juga pada organisasi sektor publik, termasuk pemerintahan. Dalam penjelasan Peraturan Pemerintah No. 56 Tahun 2005 tentang Sistem Informasi Keuangan Daerah disebutkan bahwa untuk menindaklanjuti terselenggaranya proses pembangunan yang sejalan dengan prinsip tata kelola pemerintahan yang baik (Good Governance), pemerintah, dan pemerintah daerah berkewajiban untuk mengembangkan dan memanfaatkan kemajuan teknologi informasi untuk meningkatkan kemampuan mengelola keuangan daerah, dan menyalurkan informasi keuangan daerah kepada pelayanan publik. Pemerintah perlu mengoptimalisasi pemanfaatan kemajuan teknologi informasi untuk membangun jaringan sistem informasi manajemen dan proses kerja yang memungkinkan pemerintahan bekerja secara terpadu dengan menyederhanakan akses antar unit kerja.

\section{Hasil Pengujian Hipotesis 4}

Kompetensi pegawai lebih dominan mempengaruhi kinerja pegawai pada Dinas Perindustrian dan Perdagangan Kabupaten FakFak. Setelah dilakukan pengujian analisis regresi melalui uji Beta terhadap ketiga variabel yaitu penerapan sistem informasi manajemen (X1), kompetensi pegawai (X2) dan kinerja 
pegawai (Y), ternyata variabel kompetensi pegawai ini memberikan pengaruh lebih dominan terhadap variabel kinerja pegawai, hal ini didukung dengan nilai $\mathrm{t}$ hitung untuk kompetensi pegawai (6.925) lebih besar dari pada $t$ hitung untuk penerapan sistem informasi manajemen (3.239). Sehingga hipotesis yang diajukan yang berbunyi Kompetensi pegawai lebih dominan mempengaruhi kinerja pegawai pada Dinas Perindustrian dan Perdagangan Kabupaten FakFak diterima/terbukti.

Berdasarkan hasil analisis persepsi skor rataan menunjukkan kondisi kompetensi pegawai yang baik, dimana pegawai memiliki pengetahuan tentang pekerjaan, keterampilan dalam bekerja dan perilaku terhadap sesama pegawai maupun atasan. Hal ini berarti pegawai sudah memenuhi standar kompetensi yang diterapkan oleh Dinas Perindustrian dan Perdagangan Kabupaten FakFak.

\section{Kesimpulan}

Penelitian ini telah menemukan bahwa kinerja instansi pemerintah pada Dinas Perindustrian dan Perdagangan Kabupaten FakFak dapat dijelaskan secara signifikan oleh variabel penerapan sistem informasi manajemen dan kompetensi pegawai dalam model atau tata hubung sebagai berikut;

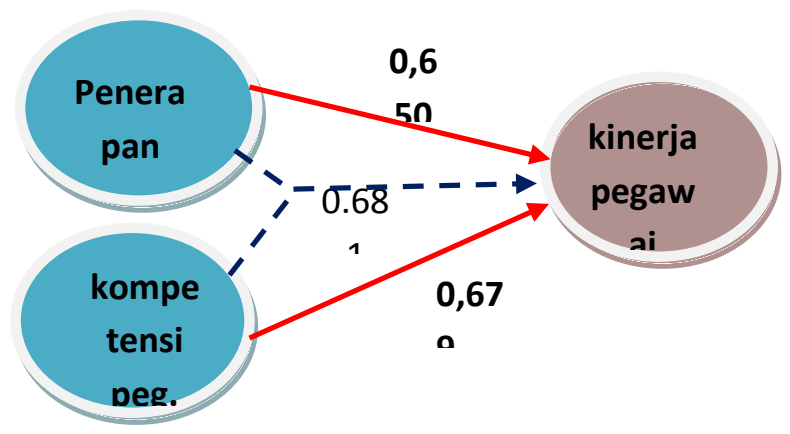

Gambar 3.

Tata Hubung antar Variabel

Temuan ini dapat menjadi alternatif model atau cara pengelolaan kinerja pegawai di Dinas Perindustrian dan Perdagangan Kabupaten FakFak. Dalam konteks ini pengaruh variabel-variabel penjelas dapat dikaji lebih lanjut untuk mendapatkan bahasan yang lebih komprehensip. Berdasarkan hasil analisis dan uji hipotesis penelitian yang telah dikakukan sebelunya maka dari penelitian ini dapat ditarik kesimpulan sebagai berikut:

1. Penerapan sistem informasi manajemen signifikan mempengaruhi kinerja pegawai di Dinas Perindustrian dan Perdagangan Kabupaten Fakfak, dengan koefisien regresi sebesar 0,650 $(p$-value $=0.000) . \quad$ Hal ini menunjukkan bahwa sangat besar peran penerapan sistem informasi manajemen bila dihubungkan dengan kinerja pegawai. Penerapan sistem informasi manajemen sangat berhubungan dengan pengolahan data, pengolahan informasi, sistem manajemen dan proses kerja elektronik.

2. Kompetensi pegawai signifikan mempengaruhi kinerja pegawai di Dinas Perindustrian dan Perdagangan Kabupaten Fakfak, dengan koefisien regresi sebesar 0,679 $(p$-value $=0.000)$. Hal ini menunjukkan bahwa kompetensi pegawai, akan mendorong naiknya kinerja instansi pemerintah secara langsung sebesar $67,9 \%$.

3. Penerapan sistem informasi manajemen dan kompetensi pegawai secara bersama signifikan mempengaruhi kinerja pegawai di Dinas Perindustrian dan Perdagangan Kabupaten Fakfak sebesar 68,1 \%. Hal ini menunjukkan bahwa dengan penerapan sistem informasi manajemen yang baik dengan pengolahan data, pengolahan informasi, sistem manajemen dan proses kerja elektronik akan mendorong naiknya kinerja pegawai sebesar 68,1\%, dan kompetensi pegawai memiliki pengaruh yang lebih dominan terhadap kinerja pegawai di Dinas Perindustrian dan Perdagangan Kabupaten Fakfak. 
Suyitno, Analisis Penerapan Sistem Informasi Manajemen dan Kompetensi Pegawai...

\section{Daftar Pustaka}

A Dale, Timpe. 1993.Kinerja Jakarta: PT. Gramedia

Anwar Mangkunegoro, 2000, Manajemen Sumberdaya Manusia, PT Remaja Rosdakarya, Bandung.

Azhar, Kasim (1984). Tantangan Terhadap Pengembangan Administrasi Publik di Indonesia. Jakarta-Jurnal Bisnis \& Birokrasi. No 2/Vol 1

Chung, Kae H and Leon C Megginsons, 1981, Organizational Behavior Developing Managerial Skills, Haper \& Row, Publisher, New York.

Flippo B Edwin, 1984, Personal Management, Mc Graw Hill, New York. Jakarta.

Gibson, H.L, 1977, Determining User Involvement, Journal of System Management, August, 20-21.

Jogiyanto, 1999, Analisis dan Desain Sistem Informasi : Pendekatan Terstruktur Teori dan Praktek Aplikasi Bisnis, ANDI Yogyakarta, Yogyakarta.

Laksamana. 2002. Pengaruh Teknologi Informasi, Saling Ketergantungan, Karakteristik Sistem Akuntansi Manajemen Terhadap Kinerja Manajerial. Jurnal Akuntansi \& Keuangan Vol. 4, No. 2, hal 241-264

Lucas, H.C, Jr, 1974, Systems Quality, User Reaction, and the Use of Information System, Journal of Management Informatics, vol 3 (4), 207-212.

Mustafa, Santiadji. 2011. Analisis Faktor Faktor Yang Berpengaruh Terhadap Keterandalan Dan Ketepatwaktuan Pelaporan Keuangan pada SKPD Pemerintah Daerah Kota Kendari. Jurnal Akuntansi Fakultas Ekonomi (online).

(http://elibrary.ub.ac.id/handle/1234 56789/32830? mode=full). Diakses 28 Oktober 2017

Nazier, Daeng M., 2009, Kesiapan SDM Pemerintah Menuju Tata Kelola Keuangan Negara Yang Akuntabel dan Transparan. Disampaikan dalam seminar nasional Badan Pemeriksa Keuangan-RI di Jakarta pada 22 Mei 2009.

Suyitno. (2017). Quality of Health Service and its Effect on Patient Satisfaction in dr Syaiful Anwar Hospital of Malang Indonesia, dalam International Journal of Advanced Research.Int.J.Adv. Res. 5(3).480488. DOI: 10.21474/IJAR01/3536.

Suyitno. (2017). Effect of Competence, Satisfaction and Discipline on Performance of Employees in the Office of Women Empowerment and Family Planning of West Papua. Dalam Jurnal Asian Social Science Vol 13 No 5 DOI: https://doi.org/10.5539/ass.v13n5p1 44

Warella, 2004. Administrasi Negara dan Kualitas Kebijakan Publik, dalam Jurnal Dialouge JIAKP. Volume 1 No 1, Januari 2004, hal 86-108

Peraturan Pemerintah RI No 56 Tahun 2005 tentang Sistem Keuangan Daerah 